\title{
PELATIHAN MENJAHIT DALAM MENINGKATKAN JIWA KEWIRAUSAHAAN PEREMPUAN DI PUSAT KEGIATAN BELAJAR MASAYARAKAT (PKBM) TIARA DEZZY SAMARINDA
}

\author{
FITRI \\ Program Studi Pendidikan Luar Sekolah \\ Universitas Mulawarman \\ Samarinda, Indonesia \\ Email : fitriaqs99@gmail.com
}

\begin{abstract}
ABSTRAK
Penelitian ini bertujuan untuk mengetahui pelaksanaan pelatihan menjahit di PKBM Tiara Dezzy Samarinda. Yang di tinjau dari perencanaan, pelaksanaan, evaluasi, tindak lanjut dan hambatan-hambatan dalam pelatihan menjahit ini. Penelitian ini merupakan Jenis penelitian yang digunakan adalah penelitian kualitatif, yaitu metode penelitian yang berlandaskan pada filsafat postpositivisme, digunakan untuk meneliti pada kondisi objek yang alamiah. Subjek penelitian ini adalah perempuan yang tidak bekerja dan yang sedang menyiapkan diri untuk bekerja tetapi tidak memiliki keterampilan. Hasil penelitian menunjukan bahwa : (1). Perencanaan pelatihan dilaksanakan tetapi masih belum maksimal karena tidak melibatkan seluruh elemen pelatihan. (2). Pelaksanaan menjahit telah dilaksanakan dengan maksimal. (3). Evaluasi meliputi evaluasi tutor dan evalasi warga belajar. (4). PKBM Tiara Dezzy memberikan pengawasan dan juga membuka usaha bersama bagi warga belajar yang telah menyelesaikan pelatihan. (5). Hambatanhambatan pelatihan seperti tenaga tutor yang kurangdan sarana dan prasarana yang kurang.
\end{abstract}

Kata Kunci : Pelatihan Menjahit, Tahapan Pelatihan, Kewirausahaan

\begin{abstract}
This study aims to determine the implementation of sewing training at PKBM Tiara Dezzy Samarinda. What is reviewed from the planning, implementation, evaluation, follow-up and obstacles in this sewing training. This research is a type of research used is qualitative research, which is a research method based on the philosophy of postpositivism, used to examine the natural conditions of objects. The subjects of this study were women who did not work and who were preparing themselves to work but did not have skills. The results showed that: (1). Training planning is implemented but it is still not optimal because it does not involve all elements of the training. (2). Sewing has been carried out to the maximum. (3). The evaluation includes the evaluation of tutors and the evaluation of learning citizens. (4). PKBM Tiara Dezzy provided supervision and also opened a joint business for learning residents who had completed the training. (5). Training barriers such as lack of tutors and lack of facilities and infrastructure.
\end{abstract}

Keywords: Tailoring Training, Training Stages, Entrepreneurship 
Jurnal Bosaparis: Pendidikan Kesejahteraan Keluarga

Volume 11, Nomor 2, Juli 2020

\section{PENDAHULUAN}

Indonesia adalah salah satu negara dengan jumlah penduduk urutan ke empat terbanyak di dunia. Menurut Badan Pusat Statistik (BPS, 2010), laju pertumbuhan penduduk di Indonesia adalah 1,49\% per tahun. Jumlah penduduk Indonesia pada 2010, sebanyak 237.341.326 jiwa. Penduduk yang bertempat tinggal di perkotaan sebanyak $49,79 \%$ dan di daerah pedesaan sebanyak 50,21\%. Penduduk laki-laki Indonesia sebanyak 119.630 .913 jiwa dan perempuan sebanyak 118.010 .413 jiwa. Sumber daya manusia yang melimpah tidak membuat Indonesia menjadi negara yang maju.

Masih banyak permasalahan yang harus di selesaikan di Indonesia, salah satunya yaitu jumlah penganguran yang terus meningkat. Berdasarkan hasil sensus penduduk (2010), jumlah penduduk usia kerja (15 tahun ke atas) adalah sebesar 169,0 juta jiwa, terdiri dari 84,3 juta orang laki-laki dan 84,7 juta orang perempuan. Dari jumlah tersebut, jumlah angkatan kerja, yakni penduduk 15 tahun ke atas yang aktif secara ekonomi yaitu mereka yang bekerja, mencari pekerjaan atau mempersiapkan usaha sebesar 107,7 juta jiwa, yang terdiri dari 68,2 juta orang laki-laki dan 39,5 juta orang perempuan. Dilihat berdasarkan daerah tempat tinggal, jumlah angkatan kerja yang tinggal di perkotaan sebesar 50,7 juta orang dan yang tinggal di perdesaan sebesar 57,0 juta orang. Dari jumlah angkatan kerja tersebut, jumlah penduduk yang bekerja sebanyak 104,9 juta jiwa dan yang mencari kerja sebesar 2,8 juta jiwa. Masalah yang muncul dari ketenagakerjaan di Indonesia, yaitu kualitas tenaga kerja yang rendah, jumlah kesempatan kerja yang rendah dan masalah pengganguran yang masih di dominasi oleh kaum perempuan. Selain itu keterlibatan perempuan ini dapat meningkatkan budaya wirausaha bagi anakanaknya, seperti yang diungkapkan oleh Mustangin (2017) bahwa Perempuan atau ibu merupakan media edukasi pertama bagi anak-anak.

Salah satu solusi yang ditawarkan yaitu masyarakat Indonesia harus mampu melihat peluang terutama dalam bidang kewirausahaan. Menurut Saragih (2017:26), Kewirausahaan merupakan kemampuan kreatif dan inovatif, jeli melihat peluang dan selalu terbuka. untuk setiap masukan dan perubahan yang positif yang mampu membawa bisnis terus bertumbuh. Seperti yang di umgkapan Alfianto (2012 : 35), kewirausahaan memiliki arti yang cukup luas, karena menyebutkan seseorang atau setiap orang, yang mampu menangkap peluangpeluang usaha, kemudian peluang usaha tersebut dijadikannya sebagai lahan bisnis dengan mencurahkan segenap waktunya untuk menciptakan peluang bisnis. Setelah tercipta peluang bisnis, seorang wirausaha akan mempertahankan jalan bisnisnya, mengembangkan jalan bisnisnya dan bahkan memperluas jaringan bisnisnya sesuai dengan tujuan utama dalam berwirausaha.

Sesuai dengan program pemerintah ditargetkan 5 juta wirausaha baru sampai dengan 2025 dengan mengembangkan sumber daya manusia untuk kemajuan wirausaha nasional. Terdapat empat masalah pokok dalam pengembangan kewirausahaan nasional, terutama sektor kecil, dan menengah, diantaranya adalah terkait dengan akses pembiayaan, akses pemasaran, regulasi birokrasi, dan kapasitas UKM. Upaya peningkatan kapasitas wirausaha, pemerintah berupaya untuk meningkatkan kualitas sumber daya manusia dalam kewirausahaan dengan tiga tahap, yaitu pembibitan, penempaan, dan pengembangan (Sukirman, 2017 : 114).

Wirausaha memiliki beberapa manfaat menurut Alfianto (2012 : 36) yang dapat dipetik oleh seorang wirausahawan dalam rangka usahanya antara lain: (1) membuka lapangan kerja baru, (2) sebagai generator pembangunan lingkungan, (3) 
Jurnal Bosaparis: Pendidikan Kesejahteraan Keluarga

Volume 11, Nomor 2, Juli 2020

sebagai contoh pribadi unggul, terpuji, jujur, berani dan tidak merugikan orang lain, (4) menghormati hukum dan peraturanyang berlaku, (5) mendidik karyawan jadi orang mandiri, disiplin, jujur dan tekun, (6) memelihara keserasian lingkungan, baik dalam pergaulan maupun dalam kepemimpinan

Keuntungan menjadi wirausaha menurut Alfianto (2012: 36) adalah : (1). Terbuka peluang untuk mencapai tujuan, (2). Terbuka peluang mendemonstrasikan potensi secara penuh, (3). Terbuka peluang memperoleh manfaat dan keuntungan secara maksimal, (4). Terbuka peluang untuk membantu masyarakat dengan usaha konkrit, dan (5). Terbuka peluang untuk menjadi bos. Selain terbuka peluang dalam mencapai tujuan, mendemonstrasikan potensi secara penuh dan memperoleh manfaat serta keuntungan secara maksimal, menjadi wirausaha adalah salah satu pilihan yang sangat menantang. Setiap wirausahawan ditantang untuk mempertaruhkan segenap waktu, pikiran, tenaga, dan energinya untuk kepentingan usaha dan bisnisnya.

Pelatihan menjadi dapat menjadi peluang berwirausaha khususnya bagi kaum wanita. Menurut Siregar dan berlianti (2017: 178) menjalankan wirausaha jasa menjahit pakaian masih menjanjikan. Meskin sekarang sudah banyak produksi pakaian jadi, tetapi jasa jahitan tetap dibutuhkan konsumen. Karena ada beberapa hal resiko pembelian baju yang biasanya di terima oleh pembeli.

Salah tempat pelatihan menjahit yaitu PKBM (Pusat Kegiatan Belajar Masyarakat) Tiara Dezzy di Samarinda. Sebagai salah satu PKBM yang telah melakukan pelatihan menjahit sejak tahun 2014. Berdasarkan hasil studi pendahuluan di ketahui bahwa hasil pelatihan yang di selenggarakan PKBM Tiara Dezzy di terapkan oleh warga belajar seperti membuka pelung usaha sendiri di sekitar tempat tinggalnya. Berdasarkan hal tersebut peneliti mengambil judul penelitian yaitu, Pelatihan Menjahit dalam Meningkatkan Jiwa Kewirausahaan Perempuan di PKBM Tiara
Dezzy Samarinda.

\section{METODE PENELITIAN}

Jenis penelitian yang digunakan adalah penelitian kualitatif, yaitu metode penelitian yang berlandaskan pada filsafat postpositivisme, digunakan untuk meneliti pada kondisi objek yang alamiah, (sebagai lawannya adalah penelitian eksperimen) dimana peneliti adalah sebagai instrument kunci, pengambilan sempel sumber data yang dilakukan secara purposive dan snowball, dan teknik pengumpulan dengan triaggulasi (gabungan), analisis data bersifat induktif/kualitatif, dan hasil penelitian kualitatif lebih menekankan makna dari pada generalisasi (Sugiyono, 2012 : 3).

Penelitian kualitatif digunakan untuk mendapatkan data yang mendalam, suatu data yang mengandug makna. Oleh karena itu dalam penelitian ini tidak menekankan pada generalisasi tetapi menekankan kepada makna. Makna dalah data yng sebenarnya, data yang pasti merupakan suatu nilai dibalik data yang tampak (Sugiyono, 2012 : 3).

Dalam penelitian kualitatif suatu realitas atau objek tidak dapat dilihat secara persial dan dipecahkan ke dalam beberapa variabel. Penelitian kualitatif memandang objek sebagai sesuatu yang dinamis, hasil dari kontruksi pemikiran, dan utuh (holistic) karena setiap aspek objek itu mempunyai kesatuan yang tidak dapat dipisahkan yang satu dengan yang lain. Realitas dalam penelitian kualitatif tidak hanya yang tampak tetapi sampai di balik yang tampak (Sugiyono, 2012: 5).

Dalam melakukan pengumpulan data terjadi interaksi antara pengumpulan data (peneliti) dengan sumber data (informaan) dan berdasarkan kepentingan masing-masing hasilnya bisa dikatakan valid. Dalam interaksi ini baik peneliti maupun sumber data memiliki latar belakang, pandang, nilai-nilai, kepentingan dan presepsi berbeda-beda, sehingga dalam pengumpulan data, analisis dan pembuatan laporan akan terikat oleh nilai masing-masing (Sugiyono, 2012 : 9).

Berdasarkan hal tersebut dapat dikemukankan bahwa, metode penelitian kualitatif itu dilakukan secara intensif, peneliti 
Jurnal Bosaparis: Pendidikan Kesejahteraan Keluarga

Volume 11, Nomor 2, Juli 2020

ikut berpartisipasi lama dilapangan, dan membuat laporan penelitian secara mendetail (Sugiyono, 2012 : 10). Sehingga data yang diperoleh relavan dengan kondisi lapangan.

Metode pengumpulan data yang digunakan dalam penelitian ini adalah observasi, wawancara, dan studi dokumen. Observasi sebagai aktivitas mencatat suatu gejala dengan bantuan isntrumen- instrumen da merekamnya dengan tujuan ilmiah atau tujuan lain (Morris dalam Hasanah, 2016 : 26). Dalam observasi akan dilakukan pencatatan, yaitu upaya merekam kejadian-kejadian menggunakan catatan lapangan, sistem katagori dan metode-metode lain. Observasi yang dilakukan berfungsi melengkapi informasi ilmiah atas gejala sosial yang diteliti melalui teknik-teknik penelitian. Dari gejala-gejala yang ada, peneliti dapat mengambil kesimpulan umum dari gejala- gejala tersebut. Observasi bukan hanya sebagai proses pengamatan dan pencatatan namun lebih dari itu observasi memudahkan peneliti mendapatkan informasi tentang dunia sekitar (Hasanah, $2016:$ 42).

Wawancara merupakan salah satu metode pengumpulan data yang paling sering digunakan dalam penelitian ilmiah. Menurut Rahardjo (2011), Wawancara ialah proses komunikasi atau interaksi untuk mengumpulkan informasi dengan cara tanya jawab antara peneliti dengan informan atau subjek penelitian. Dengan kemajuan teknologi informasi seperti saat ini, wawancara bisa saja dilakukan tanpa tatap muka, yakni melalui media telekomunikasi. Pada hakikatnya wawancara merupakan kegiatan untuk memperoleh informasi secara mendalam tentang sebuah isu atau tema yang diangkat dalam penelitian. Atau, merupakan proses pembuktian terhadap informasi atau keterangan yang telah diperoleh lewat teknik yang lain sebelumnya. Karena merupakan proses pembuktian, maka bisa saja hasil wawancara sesuai atau berbeda dengan informasi yang telah diperoleh sebelumnya.

Selain melalui wawancara dan observasi, informasi juga bisa diperoleh lewat fakta yang tersimpan dalam bentuk surat, catatan harian, arsip foto, hasil rapat, cenderamata, jurnal kegiatan dan sebagainya. Data berupa dokumen seperti ini bisa dipakai untuk menggali infromasi yang terjadi di masa silam. Peneliti perlu memiliki kepekaan teoretik

untuk memaknai semua dokumen tersebut sehingga tidak sekadar barang yang tidak bermakna (Rahardjo, 2011).

Analisis data dalam penelitian kualitatif dilakukan sejak sebelum memasuki lapangan, selama di lapangan dan setelah selesai di lapangan. Nasution (dalam Sugiyono, 2012 : 89), analisis telah dimulai sejak merumuskan dan menjelaskan masalah, sebelum terjun ke lapangan dan berlangsung terus sampai penulisan hasil penelitian. Moleong (dalam Widiastri, 2018 : 49), analisis data dilakukan terhadap data hasil wawancara (interview), pengamatan (observasi) dan dokumentasi.

Hubermen dan Miles (dalam Sugiyono, 2012 : 91), mengajukan model analisi data yang disebut sebagai model interaktif. Model interaktif terdiri dari tiga model utama, yaitu :

1. Reduksi data

Data yang diperoleh di lapangan jumlahnya cukup banyak, untuk itu maka perlu dicatat secara teliti dan rinci. Untuk itu perlu dilakukan analisis data melalui reduksi data. Mereduksi data berarti merangkum hal-hal yang pokok, memfokuskan pada hal-hal yang penting, dicari tema dan polanya. Dalam mereduksi data setiap peneliti akan dipandu oleh tujuan yang akan dicapai. Reduksi data merupakan proses berfikir sensitive yang memerlukan kecerdasan dan keluasan dan kedalaman wawasan yng tinggi.

2. Penyajian data

Setelah data direduksi, maka selanjutnya adalah menyajikan data. Penyajian data dilakukan dalam bentuk uraian singkat, bagan, hubungan kategori dan flowchart dan sejenisnya. Dengan mendisplaykan data, maka akan memudahkan untuk memahami apa yang terjadi, merencanakan kerja selanjutnya beradasarkan apa yang telah dipahami dari hasil wawancara dan observasi.

\section{Penarikan kesimpulan}

Kesimpulan awal yang dikemukakan masih bersifat sementara dan akan berubah apabila tidak ditemukan bukti-bukti yang kuat mendukung pada tahap pengumpulan data. Kesimpulan merupakan temuan baru yang sebelumnya belum pernah ada. Temuan dapat berupa deskripsi atau gambaran suatu objek 
Jurnal Bosaparis: Pendidikan Kesejahteraan Keluarga

Volume 11, Nomor 2, Juli 2020

yang sebelumnya masih dapat berubah hubungan kasual dan interaktif, hipotesis atau teori.

\section{HASIL DAN PEMBAHASAN}

Berdasarkan penelitian yang telah dilakukan di lapangan, maka diperlukan datadata yang diperlukan dalam penelitian. Mencakup intrpretasi hasil penelitian dan pengungkapan, penjelasan dan komentaran agar memperoleh makna yang berkaitan dengan permsalahan. Pembahasan tersebut menguraikan tentang pernyataan data dari deskripsi serta analisis data untuk diperoleh suatu benang merah dari hasil penelitian tersebut, sehingga pertanyaan dapat dijawab dengan pasti, yang menjadi fokus permasalahannya adalah mengenai tahapan pelatihan menjahit untuk menumpuhkan jiswa kewirausahaan. Deskripsi utama yang disajikan berisi tentang tahapan pelatihan menjahit untuk menumpuhkan jiswa kewirausahaan di PKBM Tiara Dezzy.

Untuk selanjutnya, hasil penelitian tentang tahapan pelatihan menjahit dalam menumbuhkan jiwa kewirausahaan perempuan di PKBM Tiara Dezzy Samarinda. Adapun kegiatan tersebut disajikan berdasarkan perencanaan, pelaksanaan, evaluasi dan tindak lanjut serta hambatanhambatan dalam pelaksanaan pelatihan menjahit di PKBM Tiara Dezzy.

Hasil data penelitian yang diperoleh tentang pelatihan menjahit dalam meningkatkan jiwa kewirausahaan di PKBM Tiara Dezzy Samarinda, adalah sebagai berikut :

\section{Perencanaan dalam Pelatihan Menjahit}

Hasil wawancara dan pengamatan di lapangan yang dilakukan peneliti, dengan responden yaitu pengelolah PKBM Tiara Dezzy dan tutor pelatihan menjahit PKBM Tiara Dezzy.

a. Pengelolah PKBM Tiara Dezzy.

Pelatihan menjahit merupakan program kerja tahunan dari PKBM Tiara Dezzy, sehingga pelatihan setiap tahun akan dilaksanakan. Tetapi untuk lokasi pelatihan sendiri tidak terus berada di PKBM Tiara Dezzy. Dalam memilih lokasi pelatihan

biasanya di dasari dari kebutuhan dan minat masyarakat. Tahun ini aja, pelatihan menjahit dilaksanakan di Kelurahan Pinang Seribu. Pengelolah pelatihan menjahit melakukan analisis kebutuhan di Kelurahan Pinang Seribu. Untuk materi ajar menggunakan materi ajar yang sama tetapi akan sedikit diperbarui berdasarkan keadaan masyarakatnya. Dalam pelatihan menjahit menggunakan sarana dan prasarana yang sudah ada di PKBM Tiara Dezzy.

b. Tutor Pelatihan Menjahit.

Dalam proses perencanaan pelatihan menjahit ini turor dilibatkan, dimana telah dilakukan sejak tahun kemarin, tetapi untuk pendamping tutor tidak dilibatkan. Untuk lokasi dan jadwal kegiatan pelatihan menjahit di buat oleh pengelolah PKBM Tiara Dezzy. Untuk materi ajar telah dibuat oleh pengelola, tetapi tutor telah diberikan buku pedoman/panduan untuk media ajar ini. Sarana dan prasrana menggunakan yang sudah ada sehingga perlengkapan terkadang tidak sesuai dengan jumlah warga belajar.Dari hasil wawancara di atas maka dapat di jelaskan langsung oleh peneliti bahwa perencanaan kegiatan pembelajaran di PKBM Tiara dezzy sudah dilaksanakan. Dari pemilihan lokasi pelatihan yang meliputi, analisis kebutuhan masyarakat dan antusian mayarakat dalam menyiapkan diri mereka mengikuti pelatihan ini. Untuk materi pembelajaran disusun oleh pengelola dan turor me ggunkan buku pedoman/panduan dalam pelatihan menjahit ini. Sarana dan prasarana menggunakan yang sudah ada, sehingga ketika warga belajar terkadang harus bergantian menggunakan perlengkapannya, seperti mesin jahit.

\section{Pelaksanaan Pelatihan Menjahit.}

Dari hasil pengamatan dan wawancara di lapangan yang dilakukan peneliti pada saat kegiatan pembelajaran diketahui bahwa dalam pelaksanaan kegiatan pelatihan menjahit di PKBM Tiara Dezzy, dilaksananakan pada hari senin sampai sabtu dari jam 13.00-16.00 wita. Setiap warga belajar, mendapat materi pelatihan seminggu dua kali berdasarkan dengan jadwal kelompok 
Jurnal Bosaparis: Pendidikan Kesejahteraan Keluarga

Volume 11, Nomor 2, Juli 2020

mereka.

Pembagian kelompok berdasarkan dengan alamat tempat tinggal warga belajar. Sehingga jumlah setiap kelompok tidak sama. Dan terbentuklah empat kelompok, kelompok satu dari Jalan Air Terjun No. 40 Kecamatan Samarinda Utara terdiri dari empat orang. Kelompok dua dari Jalan Pinang Seribu Gang Syukur Kecamatan Samarinda Utara terdiri dari delapan orang. Kelompok tiga dari Jalan Pinang Seribu No. 82 terdiri dari enam orang. Serta kelompok empat dari Gang Tirta Pinang Seribu terdiri dari lima orang. Tahapantahapannya yaitu kegiatan awal dan kegiatan inti. Dengan jumlah peserta latihan dua puluh tiga orang. Dan setiap kelompok didamping oleh turot dan pendamping tutor. Menggunakan sarana dan prasarana yang sudah ada misalnya mesin jahit. Tetapi terkadang warga belajar ada yang membawa alat mereka sendiri, seperti jarum jahit, pentul, dll.

\section{Evaluasi Pelatihan Menjahit}

Dari hasil wawancara dan observasi serta studi dokumentasi yang dilakukan oleh peneliti dengan responden yaitu tutor dan warga belajar adalah evaluasi terkait pembelajaran yang berbentuk laporan perkembangan warga belajar belum pernah dibuat. Dalam hal evaluasi sarana dan prasarana yang kurang tidak maksimal karena faktor pembiayaan.

Evaluasi yang berkaitan dengan warga belajar sudah dilaksanakan misalnya penugasan untuk membentuk dan memotong pola. Dan bentuk evaluasi langsung setelah pemebelajaran juga telah dilaksanakan.

Dari hasil wawancara di atas di ketahui evaluasi meliputi evaluasi tutor dan warga belajar. Hasil evaluasi belajar terhadap warga belajar tela dilaksanakan. Namun evalusi terkait materi ajar serta sarana dan prasarana belum terlaksanakan dengan maksimal.

\section{Tindak Lanjut Pelatihan Menjahit}

Dari hasil pengamatan dan wawancara di lapangan yang dilakukan peneliti pada saat tindak lanjut pelatihan menjahit diketahui bahwa dalam tindak lanjut pelatihan menjahit di PKBM Tiara Dezzy,

dilaksankan setiap hari sabtu. Dan kegiatan sekaligus untuk membuat usaha bersama di PKBM Tiara Dezzy. Dan usaha bersama ini hanya diperuntukan kepada warga belajar yang telah mengikut pelatihan menjahit di PKBM Tiara Dezzy.

Warga belajar juga mulai menerima pesanan tetapi masih di kelola oleh PKBM Tiara Dezzy. Dan selama pembentukan usaha mandiri PKBM Tiara Dezzy juga masih terus melakukan pendampingan kepada warga belajar. Dan PKBM Tiara Dezzy juga tidak membatasi warga belajar mereka yang ingin membuat usaha sendiri di rumah masingmasing.Hambatan-Hambatan Pelatihan Menjahit

Dari hasil pengamatan dan wawancara di lapangan yang dilakukan peneliti pada adapun hambatan-hambatan pelatihan menjahit di PKBM Tiara Dezzy, sebagai berikut :

A. Tutor yang tidak dilibatkan terkait penyusunan materi ajar menjadi kesulitan dalam memahami materi ajar dan hanya diberi buku panduan.

B. Warga belajar yang tidak dilibatkan dalam tahapa perencanaan sehingga pemberian kapasitas terhadapa pemanfaatan sumber daya masih kurang maksimal.

C. Usia warga belajar yang beragam, sehingga proses penerimaan materi juga beragam. Ada yang lambat meneriman dan ada yang cepat menerima materi yang diberikan.

D. Sarana dan prasarana yang masih kurang dengan jumlah warga belajar yang ada.

\section{SIMPULAN DAN SARAN}

\section{simpulan}

Berdasarkan hasil penelitian dan pembahasan, maka dapat diambil beberapa kesimpulan sebagai berikut:

1. Perencanaan pelatihan menjahit telah terlaksanaka tetapi masih kurang maksimal karena tidak 
Jurnal Bosaparis: Pendidikan Kesejahteraan Keluarga

Volume 11, Nomor 2, Juli 2020

mengikutsertakan seluruh elemen yang terlibat di dalam pelatihan menjahit.

2. Pelaksanaan pembelajar sudah terlaksana sesuai dengan perencanaan.

3. Evaluasi pembelajaran yang meliputi evaluasi tutor dan evaluasi warga belajar telah dilaksanakan oleh pengelola

4. Tindak lanjut dari pelatihan menjahit telah dilaksanakan dan tetap ada pendampingan kepada warga belajar yang sedang membuat usaha terkait dengan pelatihan.

5. Hambatan-hamabatan yang dihadapi tutor dan warga belajar seperti daya serap warga belajar dalam menerima materi. Serta sarana dan prasarana yang masih kurang dengan jumlah warga belajar yang ada.

\section{B. Saran}

Berdasarkan kesimpulan di atas, adapun saran sebagai berikut:

1. Mengingat pentingnya tahap perencanaan pelatihan pengelola PKBM Tiara Dezzy harus melibatkan seluruh elemen yang berkaitan dengan pelatihan menjahit Dalam tahap pelaksanaan perlu penambahan tutor dengan banyaknya jumlah kelompok agar dapat membantu warga belajar yang masih kurang memahami materi.

2. Evaluasi yang kurang maksimal seperti laporan pembelajaran warga belajar harus mulai dibuat.

3. Pendampingan tidaknya dilakukan dengan kelompok tetapi juga individu.

4. Sarana dan prasarana yang masih kurang di perbaiki lagi.

Elfrianto. 2016. "Manajemen Pelatihan Sumber Daya Manusia Dalam Meningkatkan Mutu Lulusan. Jurnal EduTech. Volum 2 Nomor 2

Hariyanti. 2016. "Manajemen Pelatihan Dan Pengembangan Sumber Daya Manusia Di PT Asuransi Takaful Cabang Yogyakarta". Skripsi Magister Dakwah dan Komunikasi, Universitas Islam Negeri Sunan Kalijag Yogyakarta

Kambey, Fendy Levy dan Suharnomo. 2013.

Pengaruh Pembinaan, Pelatihan dan 
Jurnal Bosaparis: Pendidikan Kesejahteraan Keluarga

Volume 11, Nomor 2, Juli 2020

Pengembangan

Pemberdayaan, dan

Partisipasi Terhadap

Kinerja Karyawan". Jurnal

Studi Manajemen Dan

Oraganisasi Volum 10

Nomor 2

Lodjo, Fernando Stefanus. 2013.

"Pengaruh Pelatihan,

Pemberdayaan dan

Efikasi Diri Terhadap

Kepuasan Kerja" Jurnal

EMBA. Volum 1 Nomor 3

Luayyi, Sri Dan Indah Yuni.

2019. "Kewirausahaan

Menjahit Bagi Masyarakat

Desa Damarwulan

Kecamatan Kepung

Kabupaten Kediri”.

Cendikia Jurnal

Pengabdian Masyarakat.

Volum 1 Nomor 1

Mustangin, M. 2017.

Perubahan Iklim dan

Aksi Menghadapi

Dampaknya: Ditinjau

dari Peran Serta

Perempuan Desa

Pagerwangi. Jurnal

Pendidikan dan

Pemberdayaan

Masyarakat. Vol.4 (1):

80-89

Nurul, Khoritin dan Tri Wilda

Afrianti. 2018. "Analisis

Pelatihan Pengembangan

Sumber Daya Manusia di

PT Beon Intermedia

Cabang Malang. Jurnal

Administrasi Bisnis. Volum

64 Nomor 1

Rohardjo, Mudjia. 2011. "Metode

Pengumpulan Data

Penelitian Kualitatif.

Universitas Islam Negeri
Maulana Malik Ibrahim

Malang https://www.UIN-

Malang-

ac.id/r/10601/metodepengumpulan-data-

penelitian- kualitatif.html

Saragih, Rintah. 2016. "Membangun

Usaha Kreatif, Inovatif dan

Bermanfaat Melalui Penerapan

Kewirausahaan Sosial".

Universitas Methodis

Indonesia. Volum 3 Nomor 1

Serigar, Mustuali. 2017.

"Kemandirian Perempuan

Melalui Keterampilan Menjahit". Jurnal Abirimas Talenta. Volum

6 Nomor 1

Sukirman. 2017. "Jiwa

Kewirausahaan dan

Nilai Kewirausahaan

Meningkatkan

Kemandirian Usaha

Melalui Perilaku

Kewirausahaan".

Universitas Maria

Kunus. Volum 20

Nomor 1

Sulaefi. 2017. "Pengaruh

Pelatihan dan

Pengembangan Terhadap

Displin Kerja dan Tenaga

Kerja Karyawan”. Jurnal

Manajemen. Volum 5

Nomor 1

Yanama, Rintih. 2015.

"Pengaruh Program

Pelatihan Menjahit

Terhadap Kemandirian

Alumni Peserta Didik Di

Pusat Kegiatan Belajar

Mayarakat (PKBM) Citra

IImu Kabupaten

Semarang. Skripsi

Magister Pendidikan Luar

Sekolah, Universitas 
Jurnal Bosaparis: Pendidikan Kesejahteraan Keluarga

Volume 11, Nomor 2, Juli 2020

Negeri Semar 